\title{
Increased Prefrontal Cortex Neurogranin Enhances Plasticity and Extinction Learning
}

\author{
Ling Zhong, ${ }^{1,2 \star}$ Joshua Brown, ${ }^{1,2 *} \oplus$ Audra Kramer, ${ }^{1,2 \star}$ Kanwardeep Kaleka, ${ }^{1,2}{ }^{\oplus}$ Amber Petersen, ${ }^{1,2}$ Jamie N. Krueger, ${ }^{4}$ \\ Matthew Florence, ${ }^{1,2}$ Matthew J. Muelbl, ${ }^{2,3}$ Michelle Battle, ${ }^{1}$ Geoffrey G. Murphy, ${ }^{4,5}$ Christopher M. Olsen, ${ }^{2,3}$ \\ and Nashaat Z. Gerges ${ }^{1,2}$ \\ ${ }^{1}$ Departments of Cell Biology, Neurobiology and Anatomy, ${ }^{2}$ Neuroscience Research Center, and ${ }^{3}$ Department of Pharmacology, Medical College of \\ Wisconsin, Milwaukee, Wisconsin 53132, ${ }^{4}$ Molecular \& Behavioral Neuroscience Institute and ${ }^{5}$ Department of Molecular and Integrative Physiology, \\ University of Michigan Medical School, Ann Arbor, Michigan 48109
}

Increasing plasticity in neurons of the prefrontal cortex $(\mathrm{PFC})$ has been proposed as a possible therapeutic tool to enhance extinction, a process that is impaired in post-traumatic stress disorder, schizophrenia, and addiction. To test this hypothesis, we generated transgenic mice that overexpress neurogranin (a calmodulin-binding protein that facilitates long-term potentiation) in the PFC. Neurogranin overexpression in the PFC enhanced long-term potentiation and increased the rates of extinction learning of both fear conditioning and sucrose self-administration. Our results indicate that elevated neurogranin function within the PFC can enhance local plasticity and increase the rate of extinction learning across different behavioral tasks. Thus, neurogranin can provide a molecular link between enhanced plasticity and enhanced extinction.

Key words: calmodulin; CaMKII; extinction; neurogranin; prefrontal cortex

\section{Introduction}

Extinction is a form of learning that occurs as an adaptive response to inhibit conditioned responses when a stimulus no longer predicts the conditioned outcome. Many disorders, such as post-traumatic stress disorder (PTSD), schizophrenia, and addictive behaviors, are associated with deficits in extinction (Milad and Quirk, 2012; Maren et al., 2013). There is substantial evidence implicating the PFC in extinction. For example, patients with PTSD or schizophrenia show reduced PFC activity and deficient extinction (Milad and Quirk, 2012). Given the importance of synaptic plasticity as a cellular correlate of learning, it is not surprising that schizophrenia and PTSD manifest with an impairment of plasticity (Nathan et al., 2011; Voineskos et al., 2013). It has been suggested that increasing plasticity of the PFC may enhance extinction and hence may be an effective therapeutic tool (Milad et al., 2006). Enhancement of extinction memory is a therapeutic strategy that has shown some promise in clinical

Received Jan. 21, 2015; revised March 3, 2015; accepted April 5, 2015.

Author contributions: L.Z., J.B., A.K., M.B., G.G.M.,C.M.O., and N.Z.G. designed research; L.Z., J.B., A.K., K.K., A.P., J.K., M.F., and M.M. performed research; L.Z., J.B., A.K., K.K., A.P., J.N.K., M.F., M.J.M., M.B., G.G.M., C.M.O., and N.Z.G. analyzed data; G.G.M., C.M.O., and N.Z.G. wrote the paper.

This work was supported by grants from U.S. National Institute on Aging (AG032320) to N.Z.G.; National Institute on Drug Abuse (DA026994) to C.M.0.; Advancing a Healthier Wisconsin and Alzheimer's Association to N.Z.G.; and the Research and Education Initiative Fund, a component of the Advancing a Healthier Wisconsin Endowment at the Medical College of Wisconsin, to N.Z.G. and C.M.O. We thank Mark Mayford for his generous gift for the constructs pMM403 and pNN265.

*L.Z., J.B., and A.K. contributed equally to this work.

The authors declare no competing financial interests.

Correspondence should be addressed to Nashaat Z. Gerges, Departments of Cell Biology, Neurobiology and Anatomy, Medical College of Wisconsin, Milwaukee, WI 53132. E-mail: ngerges@mcw.edu.

DOI:10.1523/JNEUROSCI.0274-15.2015

Copyright $\odot 2015$ the authors $\quad 0270-6474 / 15 / 357503-06 \$ 15.00 / 0$ trials (Choi et al., 2010). Thus, promoting synaptic plasticity in prefrontal circuitry may be expected to enhance extinction learning and could potentially be used as a therapeutic tool.

Neurogranin (Ng), a CaM-binding postsynaptic protein, is necessary for synaptic plasticity (Pak et al., 2000; Zhong et al., 2009). Ng regulates CaM distribution within dendritic spines and facilitates LTP by targeting CaM within dendritic spines (Zhong and Gerges, 2012; Zhong et al., 2013). Importantly, we have also shown that increasing the expression of $\mathrm{Ng}$ in organotypic hippocampal slices enhances synaptic strength and lowers the threshold for the induction of LTP (Zhong et al., 2009; Zhong and Gerges, 2010). Ng-mediated enhancement of synaptic strength is dependent on NMDA receptor activation and on Ng's ability to bind to and release CaM upon demand (Zhong et al., 2009; Zhong and Gerges, 2010, 2012). Due to this activity dependence, $\mathrm{Ng}$ can be used as a tool to facilitate plasticity in specific brain regions to measure the behavioral effects of facilitating LTP.

In this study, we explored the role of increasing $\mathrm{Ng}$ in the PFC on LTP and extinction by generating a transgenic mouse overexpressing $\mathrm{Ng}$ in the PFC. We have found that $\mathrm{Ng}$ overexpression enhances LTP in the PFC. We also show that increased PFC Ng enhances extinction learning of both positive and negative valence-conditioned responses. Our data suggest that $\mathrm{Ng}$ is a dynamic regulator of plasticity and learning. This study provides evidence that enhancing plasticity in the PFC broadly enhances extinction and suggests a possible therapeutic role for the $\mathrm{Ng}$ pathway in disorders characterized by impaired extinction.

\section{Materials and Methods}

All biosafety procedures and animal care protocols were approved by the Medical College of Wisconsin Institutional Animal Care and Use Com- 
mittee. All electrophysiological and behavioral experiments were done blind on male mice, i.e., the experimenter did not know the genotyping of the animals until after the analyses were completed.

Generating the transgenic mice and genotyping. $\mathrm{Ng}$ transgenic mice were generated by placing a full-length rat neurogranin cDNA in frame and 3' downstream of a mouse $\alpha \mathrm{Ca}^{2+}$ / CaMKII promoter ( $\alpha$ CaMKII; a gift from $\mathrm{M}$. Mayford, Scripps, La Jolla, CA). The neurogranin CDNA was flanked by synthetic $5^{\prime}$ and $3^{\prime}$ UTRs to stabilize mRNA and increase transgene expression during the transcription process (Callis et al., 1987). The final linearized transgene fragment, $\alpha$ CaMKII-3'UTR-Ng5'UTR, was $\sim 9.7 \mathrm{~kb}$ in length and was sequenced by the University of Michigan Sequencing Core before pronuclear injection. Pronuclear injections were performed by The Jackson Laboratory. Genotyping was performed by standard PCR and transgenic animals showed a distinct band using these primers: (5'-CTATAGTTGGAGGTGGGGGA GGTA- $3^{\prime}$ and $5^{\prime}$-GCTCCCATTCATCAGTT CCATAGGT-3'). Three lines were generated and screened for PFC expression. Line 1 was chosen based on expression in PFC but not in the hippocampus, amygdala, or striatum (Fig. 1).

Southern blot analysis. Mouse tail tips were digested and genomic DNA was precipitated with isopropanol and resuspended in $1 \times \mathrm{TE}$ low EDTA (10 mM Tris-HCl, pH 7.5, 0.1 mm EDTA). Following digestion, DNA was separated in a $0.7 \%$ agarose-TAE gel and transferred to Zeta-Probe GT genomic tested blotting membrane (Bio-Rad) via capillary transfer in $10 \times$ SSC. Probes generated by PCR were radiolabeled using $\alpha-{ }^{32} \mathrm{P}$-dATP and Klenow fragment was hybridized to membranes overnight in ExpressHyb solution (Clontech). Membranes were then washed and exposed to film.

$q R T-P C R$. DNase-treated total RNA isolated from hippocampus or cortex was used to generate cDNA following standard methods. qRT-PCR was performed using TaqMan assays and TaqMan Gene Expression Master Mix (Applied Biosystems). TaqMan assays to detect Neurogranin (Mm00480741_m1) and GAPDH (Mm99999915_g1) were used. Expression of Neurogranin was normalized using GAPDH.

Western blot analysis. Extracts from various brain regions were prepared in homogenization buffer containing 4 mM HEPES, pH 7.4; 320 mM sucrose; 2 mM DTT; 2 mM EDTA; $0.1 \mathrm{~mm}$ phenylmethylsulfonyl fluoride; $1 \mu \mathrm{g} / \mathrm{ml}$ leupeptin; $1 \mu \mathrm{g} / \mathrm{ml}$ chemostatin; $1 \mu \mathrm{g} / \mathrm{ml}$ antipain; and $1 \mu \mathrm{g} / \mathrm{ml}$ pepstatin. Antibodies used for Western blot analysis were anti-Ng (Millipore Bioscience Research Reagents) and anti-GAPDH (Cell Signaling Technology).

Electrophysiology. Male Ng transgenic and littermate wild-type mice were maintained on a $12 \mathrm{~h}$ light/dark cycle (lights off at 6:00 P.M.). Coronal brain slices $(350 \mu \mathrm{m})$ containing mPFC (bregma +3.20 to $+1.54 \mathrm{~mm}$ ) were cut with a vibratome (Leica VT1200) in a chamber filled with ice-cold cutting solution containing the following (in $\mathrm{mm}$ ): 26 $\mathrm{NaHCO}_{3}, 2.5 \mathrm{KCl}, 1.25 \mathrm{NaH}_{2} \mathrm{PO}_{4}, 0.5 \mathrm{CaCl}_{2}, 7 \mathrm{MgSO}_{4}, 110$ choline chloride, 25 glucose, 11.6 sodium ascorbate, and 3.1 sodium pyruvate, gassed with $5 \% \mathrm{CO}_{2} / 95 \% \mathrm{O}_{2}$.

Slices were first incubated for $30 \mathrm{~min}$ at $30 \pm 2^{\circ} \mathrm{C}$ in ACSF containing the following (in mM): $26 \mathrm{NaHCO}_{3}, 3 \mathrm{KCl}, 1.25 \mathrm{NaH}_{2} \mathrm{PO}_{4}, 2.5 \mathrm{CaCl}_{2}, 1$ $\mathrm{MgCl}_{2}, 125 \mathrm{NaCl}$, and 10 glucose (bubbled with $5 \% \mathrm{CO}_{2} / 95 \% \mathrm{O}_{2}$ ), then incubated in oxygenated $5 \% \mathrm{CO}_{2} / 95 \% \mathrm{O}_{2}$ at room temperature for at least $1 \mathrm{~h}$ before recordings. Slices were transferred to a recording cham-

\section{C qPCR}
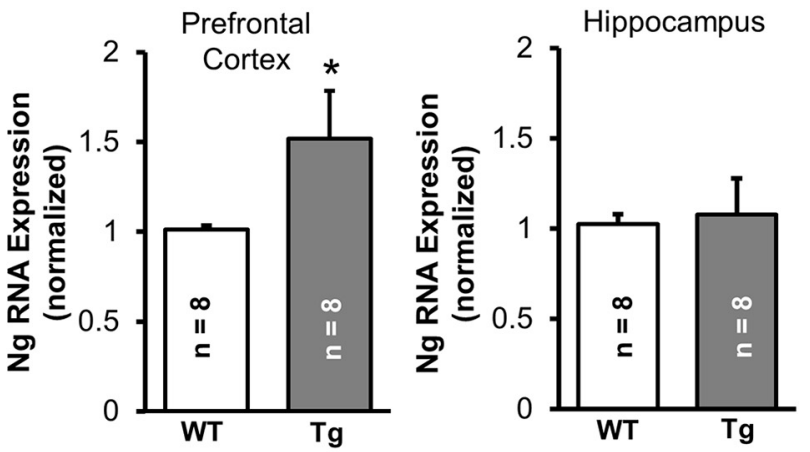

D Western blot

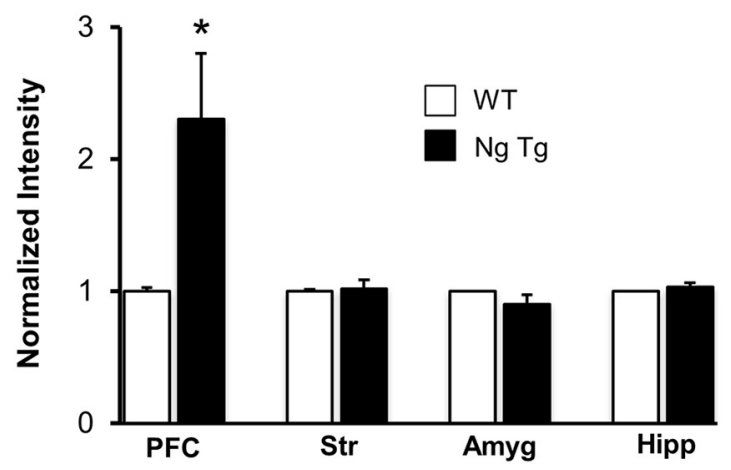

Figure 1. Biochemical characterization of the $\mathrm{Ng}$ transgenic mice. $A$, A representative Southern blot using a probe against $\mathrm{Ng}$ (capable of detecting endogenous and transgenic $\mathrm{Ng}$ ). BamHI was used to digest genomic DNA from a wild-type mouse (WT), the e founder ( $(F 0)$, two different mice from first generation (F1), and one second-generation mouse (F2). B, A representative analysis in different brain regions. Str, striatum; Amyg, amygdala; Hipp, hippocampus. Ng level was significantly higher in the PFC in the NgTg mice $\left(t_{(15)}=2.629, p<0.05\right)$. Data presented as mean \pm SEM.

ber with oxygenated ACSF with $100 \mu \mathrm{M}$ picrotoxin to block inhibitory GABAergic transmission. mPFC pyramidal neurons were identified under visual guidance using differential interference contrast illumination. For I/O curve, stimuli were delivered by a bipolar electrode placed on layer II/III of the prelimbic PFC, and fEPSPs were recorded using electrodes $(3-6 \mathrm{M} \Omega$ ) that were filled with ACSF and were placed in layer V of the prelimbic PFC. LTP was induced by a tetanus stimulation consisting of $100 \mathrm{~Hz}$ stimuli (100 pulses), repeated five times every $10 \mathrm{~s}$.

Fear conditioning. For auditory fear conditioning, we used a similar protocol as described previously (Tang et al., 2001). Briefly, on day 1, mice were placed individually into a standard conditioning mouse chamber (Coulbourn) within a sound- and light-attenuating box illuminated by one $25 \mathrm{~W}$ bulb. The experimental contingencies were controlled by a computer via FreezeFrame software from Coulbourn. Mice were placed in the chamber for $3 \mathrm{~min}$ (baseline) before presenting a $20 \mathrm{~s}, 80 \mathrm{~dB}$, and $3 \mathrm{kHz}$ tone. During the last $2 \mathrm{~s}$ of the tone, a $0.5 \mathrm{~mA}$ footshock was delivered through the grid floor. The pairing was repeated seven times to strengthen the association between the tone and the shock. Memory was assessed $24 \mathrm{~h}$ later by measuring the amount of time mice exhibited freezing in response to the tone (tested in a novel context that differs in scent, color/texture of walls and floor, and illumination). For the extinction testing, 10 tones (separated by $200 \mathrm{~s}$ ) were presented without a footshock every $24 \mathrm{~h}$ after conditioning for 5 consecutive days.

Sucrose-reinforced operant conditioning. Operant training took place in chambers as described previously (Olsen and Winder, 2009) with the exception that the chambers were equipped with retractable levers on the left wall (retracted and not used in this study) and nose-poke manipulanda on the right wall $(1.4 \mathrm{~cm}$ above the floor), with a liquid receptacle 

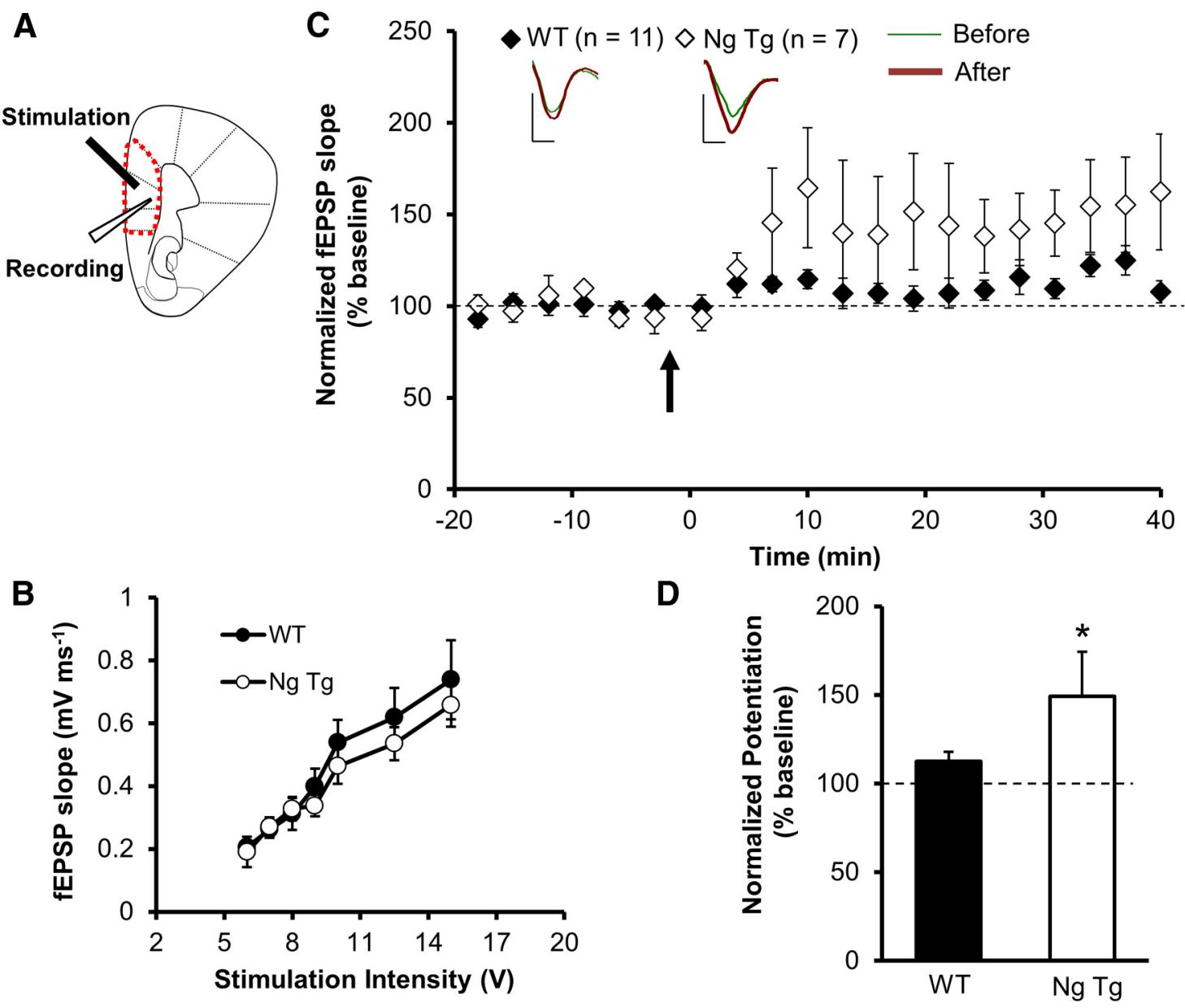

Figure 2. Increased Ng at PFC enhances LTP. A, Schematic illustration of MPFC as outlined by the red dashed lines. Stimuli were delivered to layer II/III pyramidal neurons of the prelimbic cortex while responses were recorded from layer V neurons. $\boldsymbol{B}$, Input- output curves of evoked monosynaptic responses at layer V synapses in the PFC in wild-type and Ng transgenic mice. $\boldsymbol{C}$, LTP was induced by tetanic stimulation (indicated with an arrow) of layer II/III of the PFC and measured from layer V of PFC. $D$, Normalized average steady-state AMPAR-mediated responses (25-40 min after induction) for $\mathrm{NgTg}(n=7)$ and WT $(n=11)$ were evaluated by Student's $t$ test $(t=1.747, p<0.05)$. Data presented as mean \pm SEM.

mounted in between the nose-poke holes. Yellow cue lights were mounted $5.8 \mathrm{~cm}$ above each of the manipulanda. Either the left or right nose poke was designated as active (counterbalanced within each genotypes), and a response on the active nose poke resulted in delivery of $10 \%$ sucrose ( $35 \mu$ l delivered over $1.98 \mathrm{~s}$ via syringe pump) and $5 \mathrm{~s}$ illumination of the cue light located inside the nose poke and the cue lights above each of the nose pokes. Nose pokes on the inactive hole were recorded but had no consequence. Each session began with illumination of the house light, turning on the chamber fan, and a single noncontingent delivery of sucrose and cue. Sessions were terminated when the maximum of 35 reinforcers was earned or after $1 \mathrm{~h}$ was reached. Mice acquired the operant task in 10 sessions [sessions $1-7$ were under free-feeding conditions, sessions 8-10 were under food restriction ( $6 \mathrm{~h}$ food access per day)]. Next, mice underwent extinction testing with cues, where all conditions were identical, but no liquid was delivered in response to active nose poke. Mice were tested in $3 \mathrm{~h}$ extinction sessions with cues (E1-E3): sessions E1 and E2 were separated by $24 \mathrm{~h}$, session E3 was $72 \mathrm{~h}$ after E2. After a single $3 \mathrm{~h}$ extinction session without cues (no cue light or activation of pump), all mice underwent reacquisition of the operant behavior (active nose poke once again resulted in delivery of sucrose and $5 \mathrm{~s}$ cue light; three to five sessions until two consecutive sessions of $\geq 30$ reinforcers). After reacquisition, mice were exposed to a single $5 \mathrm{~h}$ extinction session without cues (no consequence of active or inactive nose poke).

Statistical analysis. For fear extinction and sucrose self-administration experiments, data were analyzed by two-way repeated-measures ANOVAs [Factor A: genotype; Factor B: session (repeated)] and HolmSidak multiple comparisons. In cases where tests of normality or heter- ogeneity of variance were violated, analyses were performed on ranked values. For other behavioral testing and electrophysiology, Student's $t$ test was used to compare NgTg mice to their wild-type littermates. Significance was defined as $p<0.05$.

\section{Results}

Increased $\mathrm{Ng}$ at mPFC enhances LTP

To test the hypothesis that enhanced synaptic plasticity in the PFC promotes extinction learning we developed a transgenic mouse line that overexpresses $\mathrm{Ng}$ in the PFC (but not in the hippocampus, amygdala, or striatum; Fig. 1). We first performed blind experiments to investigate the effect of $\mathrm{Ng}$ overexpression on synaptic transmission and plasticity in the mPFC. Basal synaptic transmission was not altered by chronic in vivo elevation of $\mathrm{Ng}$. Field recordings from layer $\mathrm{V}$ of the $\mathrm{mPFC}$ revealed that LTP was significantly increased in the $\mathrm{Ng}$ transgenic mice (Fig. 2). This supports a rate-limiting role of $\mathrm{Ng}$ in enhancing plasticity in vivo.

\section{Enhanced extinction of conditioned fear in NgTg mice}

To test the role of enhancing PFC plasticity on fear conditioning and extinction learning, we subjected the $\mathrm{Ng}$ transgenic mice (NgTg) to cued fear conditioning, followed by extinction training. During conditioning trials, NgTg mice showed similar freezing levels during the tone when compared with their wild-type littermates (Fig. 3A). Interestingly, when tested in a novel context 
A

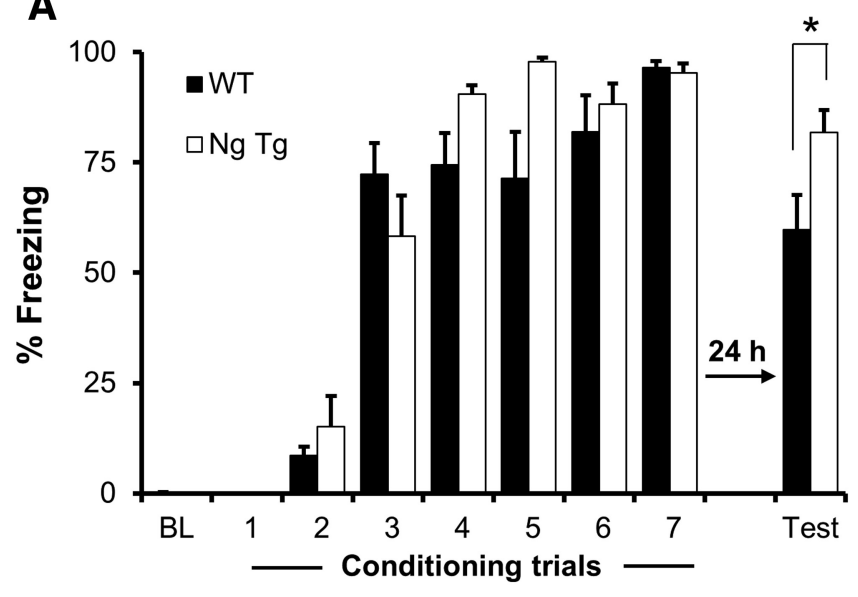

B

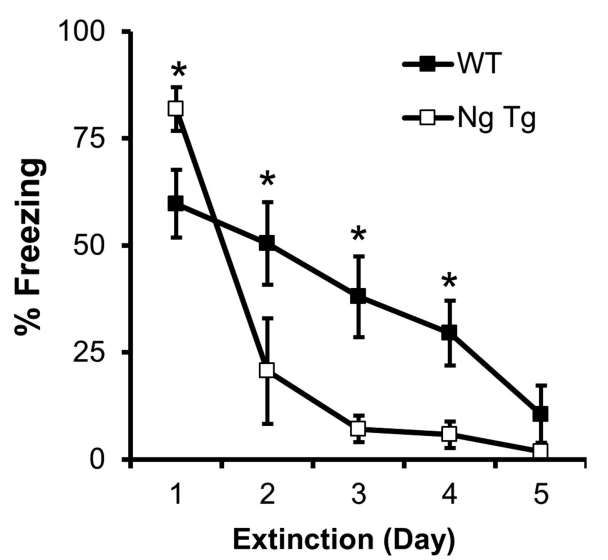

Figure 3. Enhanced extinction of conditioned fear in $\mathrm{NgTg}$ mice. $\boldsymbol{A}$, After $3 \mathrm{~min}$ baseline (BL), each mouse received seven conditioning trials. Graph shows percentage time spent freezing during the tone. $\mathrm{NgTg}$ mice $(n=6)$ show significantly higher freezing during the cued test $24 \mathrm{~h}$ after conditioning than WT mice $(n=10)$. $\boldsymbol{B}$, The seven conditioning trials $(\boldsymbol{A})$ were followed by 5 d extinction (10 tones each day without presence of shock). Graph shows the average of percentage time spent freezing during the first two tones. Two-way ANOVA revealed a statistically significant interaction $(p<0.05)$ between genotype and trial $(F=2.79) .{ }^{*} p<0.05$ at given trials using Holm-Sidak post hoc test. Data presented as mean \pm SEM.

24 h later, NgTg mice exhibited more freezing during the tone presentation (Fig. $3 A$ ), supporting the notion that PFC plays a significant role in cued fear memory (Milad and Quirk, 2002). Importantly, despite the initial high magnitude of cued memory, NgTg mice exhibited significantly faster extinction (Fig. 3B). This provides the first evidence that $\mathrm{Ng}$ plays a rate-limiting role in extinction learning. To ensure that the lower freezing at day 3 is not due to forgetting per se, we have performed a similar experiment where we have tested memory $72 \mathrm{~h}$ after acquisition. $\mathrm{NgTg}$ mice sustained a high memory $72 \mathrm{~h}$ after acquisition (WT: $n=5$, Freezing $=71.9 \pm 3.9 \%$ SEM; NgTg: $n=4$, Freezing $=72.6 \pm$ 6.9 SEM, $t=0.243, p=0.41$ ). It is also worth noting that these NgTg mice exhibited comparable hippocampal-dependent spatial learning and memory as evidenced by their performance in the radial-arm water-maze task (WT: $n=13$, average errors $24 \mathrm{~h}$ after acquisition $=2.1 \pm 0.43$ SEM; NgTg: $n=11$, errors $=$ $2.36 \pm 0.57 \mathrm{SEM}, t=0.371, p=0.72$ ). These NgTg mice were also indistinguishable from their wild-type littermates in general physical characteristics, general behavioral observations, and sensorimotor reflexes (data not shown).

\section{Enhanced extinction of operant response and food seeking in NgTg mice}

PFC function has been linked to extinction of both negative and positive valence-learned associations (Peters et al., 2009; Peters and De Vries, 2013). Thus, if Ng overexpression in the PFC enhances extinction learning in general, this phenomenon should also be observed in the context of a completely different behavior. To this end, $\mathrm{Ng}$ transgenic mice and their littermates were trained to self-administer $10 \%$ sucrose in a nose poke-based operant conditioning task, then underwent extinction sessions. WT and NgTg mice were no different in acquisition, although nose-poke rates in NgTg mice were greater (WT: $n=8$, active nose pokes/ $\min =1.26 \pm 0.09$ SEM; NgTg: $n=6$, active nose pokes $/ \mathrm{min}=$ $1.76 \pm 0.15 \mathrm{SEM}, t=2.85, p<0.05)$. After acquisition, mice underwent $3 \mathrm{~d}$ of extinction sessions where active nose pokes resulted in cue, but not sucrose delivery. Within both the first session (Fig. 4A) and across the three extinction days (Fig. 4B), $\mathrm{NgTg}$ mice unexpectedly took longer than WT to significantly reduce nose poking under extinction conditions. One possibility for this finding is that the cue maintained a conditioned reinforc- ing value, which interfered with extinction of nose-poke responses (Mackintosh, 1974). To directly examine extinction of food seeking, we measured head entries into the food receptacle. This analysis revealed a rapid decline in head entries in transgenic mice but not WT during the initial session (Fig. 4C,D). To determine whether reduced extinction of nose-poke responses in NgTg mice was associated with cue delivery, mice were retrained and subjected to extinction where nose-poke responses had no consequence (no cues) in a single $5 \mathrm{~h}$ session. Under these conditions, NgTg mice showed a greater reduction than WT in both nose-poke responses and head entries within the first hour (Fig. $4 E, F)$, indicating that extinction of both the operant response and food seeking were enhanced in the NgTg mice.

\section{Discussion}

$\mathrm{Ng}$ is a neuron-specific postsynaptic protein that is abundant at dendritic spines. Through its IQ motif, $\mathrm{Ng}$ binds to CaM, a required molecule for the activation of CaMKII, which is key in LTP induction. Two main views exist regarding the relevance of $\mathrm{Ng}$ binding to $\mathrm{CaM}$ in neurons. According to one view, $\mathrm{Ng}$ negatively modulates $\mathrm{CaM}$ and constrains $\mathrm{Ca}^{2+} / \mathrm{CaM}$-mediated signaling (Martzen and Slemmon, 1995; Krucker et al., 2002). The other view, however, suggests that $\mathrm{Ng}$ concentrates and targets CaM within the spine and enhances the probability of inducing LTP (Gerendasy, 1999; Prichard et al., 1999; Zhabotinsky et al., 2006). In support of the latter view, we have previously shown that overexpressing $\mathrm{Ng}$ in the pyramidal neurons of the hippocampus facilitates LTP through the regulated targeting of CaM within dendritic spines (Zhong et al., 2009; Zhong and Gerges, 2012). In this study, we further examined the role of $\mathrm{Ng}$ in LTP and extinction learning in a transgenic mouse overexpressing $\mathrm{Ng}$ in the PFC.

Using these NgTg mice, we show that increasing $\mathrm{Ng}$ in the PFC facilitates LTP. This is in support of our previous studies showing that increasing $\mathrm{Ng}$ in the hippocampus facilitates LTP (Zhong et al., 2009; Zhong and Gerges, 2012). These results suggest a more unified model for the molecular mechanism of $\mathrm{Ng}$ function, where increasing $\mathrm{Ng}$ within a specific brain region facilitates LTP and improves learning of tasks associated with that region. It is worth noting that a computational study has also supported a need for a higher concentration of $\mathrm{Ng}$ in the spines to 

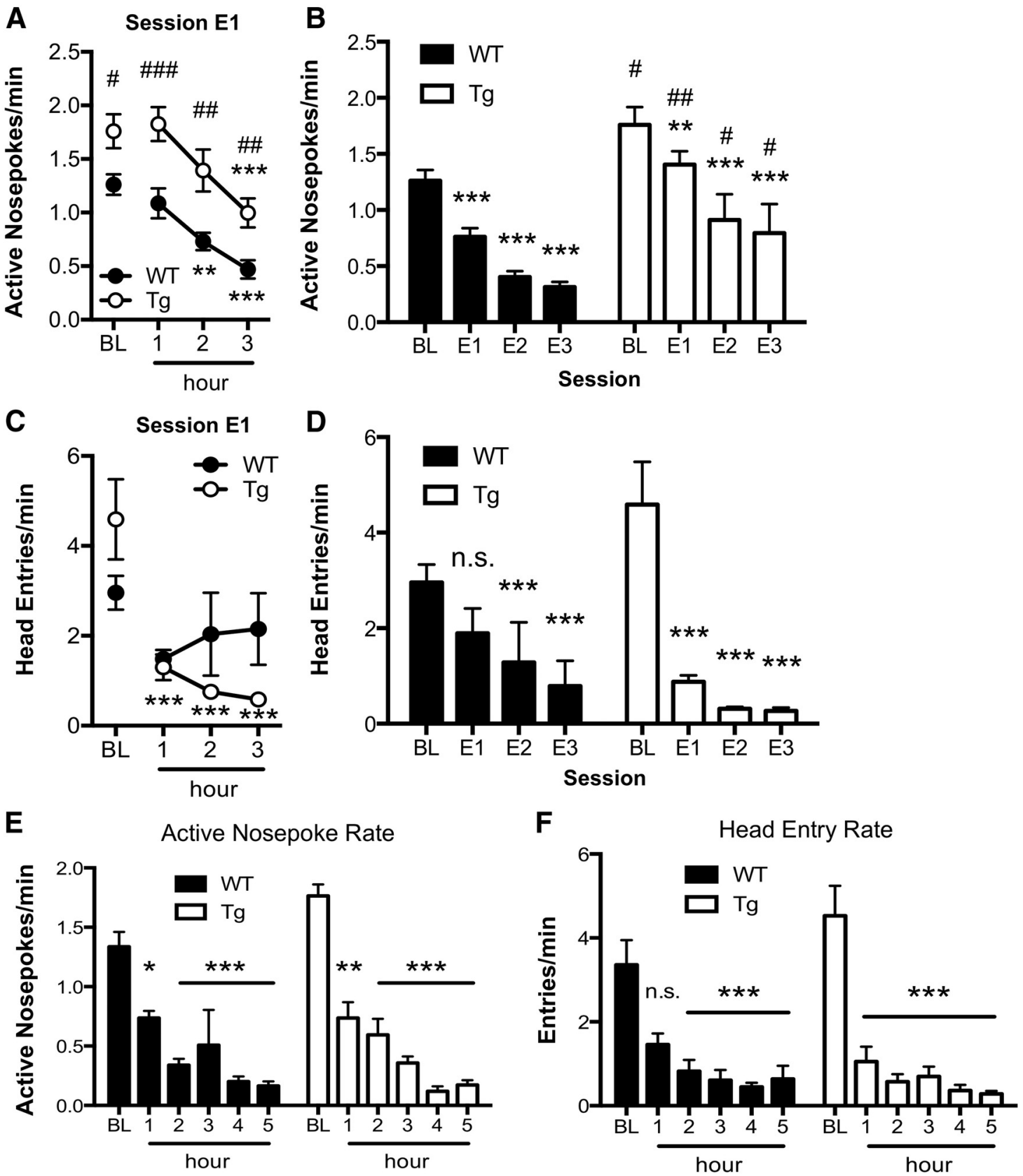

Figure 4. Enhanced extinction of operant response and food seeking in NgTg mice. $A$, Nose-poke rate in the active hole during baseline (BL) and individual $3 \mathrm{~h}$ of first cued extinction session. Significant effect of genotype $\left(F_{(1,36)}=22.3, p<0.001\right)$ and session $\left(F_{(3,36)}=22.2, p<0.001\right)$. B Active nose-poke rate during $B L$ and subsequent $3 \mathrm{~d}$ of extinction. Significant effect of genotype $\left(F_{(1,36)}=10.4, p<0.01\right)$ and session $\left(F_{(3,36)}=69.7, p<0.001\right)$. C, Head entry rate during BL and first cued extinction session. Significant effect of session $\left(F_{(3,36)}=8.5, p<0.001\right)$ and genotype $\times$ session interaction $\left(F_{(3,5)}=3.1, p<0.05\right)$. D. Head-entry rate during $B$ L and subsequent 3 d of noncued extinction. Significant effect of session $\left(F_{(3,36)}=50.7, p<0.001\right) . E, F$, Active nose-poke rate $(\boldsymbol{E})$ and head-entry rate $(\boldsymbol{F})$ during a single extinction session without paired cues. $\boldsymbol{E}$, Significant effect of session $\left(F_{(5,60)}=49.2, p<0.001\right)$. $\boldsymbol{F}$, Significant effect of session $\left(F_{(5,60)}=\right.$ 23.2, $p<0.001$ ). Within group significance: ${ }^{*} p<0.05,{ }^{* *} p<0.01,{ }^{* * *} p<0.001$; between-group significance: ${ }^{*} p<0.05,{ }^{\#} p<0.01$. Data presented as mean \pm SEM.

be able to induce LTP (Zhabotinsky et al., 2006). Moreover, we have also shown that knocking down $\mathrm{Ng}$ using small interference RNA blocks LTP (Zhong et al., 2009), supporting knock-out studies by Huang et al. (2004) showing that $\mathrm{Ng}$ is required for LTP and learning (Pak et al., 2000). These data indicate that dynamic changes in $\mathrm{Ng}$ levels control the expression of LTP and highlight the bidirectional role of $\mathrm{Ng}$ in the regulation of synaptic potentiation.

To test the hypothesis that LTP facilitation in the PFC enhances extinction learning, we have tested the role of increasing $\mathrm{Ng}$ in the PFC on extinction of both negative and positive valence-conditioning responses. We show that NgTg mice have an enhanced rate of extinction of both learned fear conditioning and sucrose self-administration. This demonstrates a critical role of $\mathrm{Ng}$ in regulating extinction.

This study also raises important questions regarding the possible therapeutic value of $\mathrm{Ng}$ in various neurological disorders in general and in schizophrenia in particular. While decreased $\mathrm{Ng}$ levels are generally correlated with deficits in learning and memory, it was not known whether increasing $\mathrm{Ng}$ would result in enhanced learning. For example, low $\mathrm{Ng}$ levels were correlated with poor performance in the Morris water maze (Huang et al., 
2004). In addition, many conditions that are associated with memory deficits are also associated with low levels of $\mathrm{Ng}$ in pyramidal neurons, e.g., aging and hypothyroidism (Iñiguez et al., 1993; Piosik et al., 1995; Chang et al., 1997; Mons et al., 2001). Moreover, a genome-wide association study shows that $\mathrm{Ng}$ is one of the major variants that correlates with schizophrenia, which may explain the extinction deficits associated with schizophrenia (Stefansson et al., 2009). This current study is the first study to show that increasing $\mathrm{Ng}$ results in enhanced learning. In particular, increasing Ng levels in the PFC enhances extinction learning, strongly suggesting a critical role of $\mathrm{Ng}$ and its bidirectional regulation of learning.

In conclusion, our findings show that enhancing plasticity in the PFC is sufficient to enhance extinction learning of both negative and positive valence-conditioned responses using two different types of tasks (pavlovian vs operant conditioning). These data suggest that $\mathrm{Ng}$ signaling in the PFC may be a specific therapeutic target for the treatment of disorders that are characterized by impaired extinction of fearful stimuli, e.g., PTSD, or of reward-associated stimuli, e.g., drug addiction.

\section{References}

Callis J, Fromm M, Walbot V (1987) Introns increase gene expression in cultured maize cells. Genes Dev 1:1183-1200. CrossRef Medline

Chang JW, Schumacher E, Coulter PM 2nd, Vinters HV, Watson JB (1997) Dendritic translocation of RC3/neurogranin mRNA in normal aging, Alzheimer disease and fronto-temporal dementia. J Neuropathol Exp Neurol 56:1105-1118. CrossRef Medline

Choi DC, Rothbaum BO, Gerardi M, Ressler KJ (2010) Pharmacological enhancement of behavioral therapy: focus on posttraumatic stress disorder. Curr Top Behav Neurosci 2:279-299. CrossRef Medline

Gerendasy D (1999) Homeostatic tuning of $\mathrm{Ca}^{2+}$ signal transduction by members of the calpacitin protein family. J Neurosci Res 58:107-119. CrossRef Medline

Huang KP, Huang FL, Jäger T, Li J, Reymann KG, Balschun D (2004) Neurogranin/RC3 enhances long-term potentiation and learning by promoting calcium-mediated signaling. J Neurosci 24:10660-10669. CrossRef Medline

Iñiguez MA, Rodriguez-Peña A, Ibarrola N, Aguilera M, Muñoz A, Bernal J (1993) Thyroid hormone regulation of RC3, a brain-specific gene encoding a protein kinase-C substrate. Endocrinology 133:467-473. CrossRef Medline

Krucker T, Siggins GR, McNamara RK, Lindsley KA, Dao A, Allison DW, De Lecea L, Lovenberg TW, Sutcliffe JG, Gerendasy DD (2002) Targeted disruption of RC3 reveals a calmodulin-based mechanism for regulating metaplasticity in the hippocampus. J Neurosci 22:5525-5535. Medline

Mackintosh NJ (1974) The psychology of animal learning. London: Academic.

Maren S, Phan KL, Liberzon I (2013) The contextual brain: implications for fear conditioning, extinction and psychopathology. Nat Rev Neurosci 14:417-428. CrossRef Medline

Martzen MR, Slemmon JR (1995) The dendritic peptide neurogranin can regulate a calmodulin-dependent target. J Neurochem 64:92-100. CrossRef Medline

Milad MR, Quirk GJ (2002) Neurons in medial prefrontal cortex signal memory for fear extinction. Nature 420:70-74. CrossRef Medline
Milad MR, Quirk GJ (2012) Fear extinction as a model for translational neuroscience: 10 years of progress. Annu Rev Psychol 63:129-151. CrossRef Medline

Milad MR, Rauch SL, Pitman RK, Quirk GJ (2006) Fear extinction in rats: implications for human brain imaging and anxiety disorders. Biol Psychol 73:61-71. CrossRef Medline

Mons N, Enderlin V, Jaffard R, Higueret P (2001) Selective age-related changes in the PKC-sensitive, calmodulin-binding protein, neurogranin, in the mouse brain. J Neurochem 79:859-867. CrossRef Medline

Nathan PJ, Cobb SR, Lu B, Bullmore ET, Davies CH (2011) Studying synaptic plasticity in the human brain and opportunities for drug discovery. Curr Opin Pharmacol 11:540-548. CrossRef Medline

Olsen CM, Winder DG (2009) Operant sensation seeking engages similar neural substrates to operant drug seeking in C57 mice. Neuropsychopharmacology 34:1685-1694. CrossRef Medline

Pak JH, Huang FL, Li J, Balschun D, Reymann KG, Chiang C, Westphal H, Huang KP (2000) Involvement of neurogranin in the modulation of calcium/calmodulin-dependent protein kinase II, synaptic plasticity, and spatial learning: a study with knockout mice. Proc Natl Acad Sci U S A 97:11232-11237. CrossRef Medline

Peters J, De Vries TJ (2013) D-cycloserine administered directly to infralimbic medial prefrontal cortex enhances extinction memory in sucroseseeking animals. Neuroscience 230:24-30. CrossRef Medline

Peters J, Kalivas PW, Quirk GJ (2009) Extinction circuits for fear and addiction overlap in prefrontal cortex. Learn Mem 16:279-288. CrossRef Medline

Piosik PA, van Groenigen M, Ponne NJ, Bolhuis PA, Baas F (1995) RC3/ neurogranin structure and expression in the caprine brain in relation to congenital hypothyroidism. Brain Res Mol Brain Res 29:119-130. CrossRef Medline

Prichard L, Deloulme JC, Storm DR (1999) Interactions between neurogranin and calmodulin in vivo. J Biol Chem 274:7689-7694. CrossRef Medline

Stefansson H, Ophoff RA, Steinberg S, Andreassen OA, Cichon S, Rujescu D, Werge T, Pietiläinen OP, Mors O, Mortensen PB, Sigurdsson E, Gustafsson $\mathrm{O}$, Nyegaard M, Tuulio-Henriksson A, Ingason A, Hansen T, Suvisaari J, Lonnqvist J, Paunio T, Børglum AD, et al. (2009) Common variants conferring risk of schizophrenia. Nature 460:744-747. CrossRef Medline

Tang YP, Wang H, Feng R, Kyin M, Tsien JZ (2001) Differential effects of enrichment on learning and memory function in NR2B transgenic mice. Neuropharmacology 41:779-790. CrossRef Medline

Voineskos D, Rogasch NC, Rajji TK, Fitzgerald PB, Daskalakis ZJ (2013) A review of evidence linking disrupted neural plasticity to schizophrenia. Can J Psychiatry 58:86-92. Medline

Zhabotinsky AM, Camp RN, Epstein IR, Lisman JE (2006) Role of the neurogranin concentrated in spines in the induction of long-term potentiation. J Neurosci 26:7337-7347. CrossRef Medline

Zhong L, Gerges NZ (2010) Neurogranin and synaptic plasticity balance. Commun Integr Biol 3:340-342. CrossRef Medline

Zhong L, Gerges NZ (2012) Neurogranin targets calmodulin and lowers the threshold for the induction of long-term potentiation. PLoS One 7:e41275. CrossRef Medline

Zhong L, Cherry T, Bies CE, Florence MA, Gerges NZ (2009) Neurogranin enhances synaptic strength through its interaction with calmodulin. EMBO J 28:3027-3039. CrossRef Medline

Zhong L, Brown JC, Wells C, Gerges NZ (2013) Post-embedding Immunogold labeling of synaptic proteins in hippocampal slice cultures. J Vis Exp 74:e60273. CrossRef Medline 